Article

\title{
Spatio-Temporal Patterns of Cropland Conversion in Response to the "Grain for Green Project" in China's Loess Hilly Region of Yanchuan County
}

\author{
Jieyong Wang, Yansui Liu and Zhigao Liu * \\ Institute of Geographic Sciences and Natural Resources Research (IGSNRR), \\ Chinese Academy of Sciences, Beijing 100101, China; E-Mails: wjy@igsnrr.ac.cn (J.W.); \\ liuys@iganrr.ac.cn (Y.L.) \\ * Author to whom correspondence should be addressed; E-Mail: liuzhigao@igsnrr.ac.cn; \\ Tel.: +86-10-6488-9529; Fax: +86-10-6488-9034.
}

Received: 20 September 2013; in revised form: 22 October 2013 / Accepted: 24 October 2013 / Published: 30 October 2013

\begin{abstract}
To prevent environmental degradation, China's central government launched the "Grain for Green Project" (GGP) in 1999. Since its beginning, the effects and influences of the GGP have been hotly debated among domestic and international scholars and policymakers. This paper is taking the County of Yanchuan in the Loess Plateau as a case study, examines the spatio-temporal patterns of cropland conversion in response to the GGP. This research is methodologically based on remote sensing (RS) and geographic information systems (GIS), and also employs personal interviews with local government officials and farmers. The results show that land use/cover patterns in Yanchuan County have changed dramatically after the implementation of GGP. Cropland has decreased remarkably, while orchard land and sparse forest has increased significantly: $23.84 \%$ of cropland was converted to orchard, and $22.25 \%$ to sparse forest. Simultaneously, the landscape has become more fragmented but also more diversified, forestland has become more dominant. A total of $61.19 \%$ of the total converted cropland was on slopes greater than 15 degrees, $64.85 \%$ of which was lower-grade land. The converted cropland is mostly located in more accessible areas for convenient management. Partially affected by farmers' self-willingness, sloping cropland was preferred to orchard (economic forest), and some gentle slope (less than 15 degrees) or higher-grade cropland were involved in the GGP. To maintain and reinforce the achievements of the GGP and further contribute to the GGP's sustainability and rural development, the paper recommends that the Chinese government should build a continuous compensation mechanism for the households who lost cropland for the GGP while improving the productivity of flat cropland.
\end{abstract}


Keywords: cropland conversion; spatio-temporal; GGP effects; the Loess Plateau; China

\section{Introduction}

It has been widely recognized that China, over the years, has experienced severe environmental degradation. The Chinese Government, in recent years, has made efforts to rescue the degraded environment [1,2]. Among these efforts, the "Grain for Green Project" (GGP), also known as the "Sloping Land Conversion Program" (SLCP), is an extremely ambitious conservation program to prevent soil erosion. With a budget of RMB 337 billion (over US\$ 40 billion), from 2000 to 2010, the project also is one of the world's largest land conservation programs [3]. In fact, such large scale conservation programs at the national level have been implemented in other countries, for example, the Conservation Reserve Program (CRP) in American and ari-environmental schemes in UK.

Given the large scale and profound influence of the state-funded project, the social, economic, and ecological impacts of the GGP have been well documented, including the ecological effects [4,5], effects on rural socio-economic development [6], farmers' attitude [7], grain output [8,9], and so on. However, the existing studies have often taken the converted cropland as a whole, and have not paid due attention to the internal differences among the cropland conversion, for example, in terms of its slope, location, and quality. Thus, this paper tries to fill this gap, namely, to give some answers to these intertwined issues largely by using Remote Sensing (RS) and Geographic Information Systems (GIS): what kinds of cropland were converted, and to which kinds of forest?

Sloping cropland is not only the targeted land for national reforestation and ecological restoration projects, but also a main source of livelihood for thousands of farmers who have carried out the GGP policy in practice. Therefore, the implementation of GGP necessarily involves multiple actors, from the highest-level government to the lowest-level government to the individual farmers. This results in a problem - how to coordinate the inter-scalar interest conflicts. Among them, farmers are the core actors to carry out the GGP [10], as they on the one hand need to meet the requirement of the government-issued GGP, and on the other hand hope to maintain and increase their economic income through engagement with the GGP. Farmers have been asked to convert their sloping cropland that are prone to erosion in return for gaining provisions and cash subsidies as well as benefiting from the resulting forests, for example by reaping fruit from orchards. However, although government payments have been transferred to farmers, they have not been sufficient to support the livelihood of farmers who have lost cropland. As different types of forests have different economic and ecological value, farmers could take full advantage of these differences in order to meet the ecological goals of the government, and also to protect their own economic interest at the same time. Yet, the cropland conversion does not always meet the full requirements of GGP.

The overall goal of this paper is to provide a case study of the spatio-temporal patterns of cropland conversion responses to the GGP. We focused on what kinds of cropland that have been converted to what kinds of afforestation, using Yanchuan County in the Loess Plateau as a case study. The Loess Plateau, located in the upper and middle reaches of the Yellow River, is a priority region for the GGP due to its severe soil erosion and water loss, which has been caused largely by improper anthropogenic land use activities such as over-cultivation, overgrazing, and over-deforestation $[11,12]$. 
Multiple research methods are employed in this paper. High spatial resolution RS data were well used to map the CRP land in American and also evaluate the status and success of the program [13]. Following standard analytical techniques to study land-use and land-cover change [14-17], we use RS and GIS to detect the spatio-temporal characteristics of land transformation: high spatial resolution RS data enables us to obtain valuable multi-temporal data for monitoring patterns and processes of cropland conversion, and GIS makes spatial analysis and mapping of these patterns possible [18]. At the same time, we employed personal interviews with local government officials and farmers to investigate the reasons and motives behind the changes of the land use patterns.

The remainder of the paper is organized as follows. In Section 2, we summarize the process the overview of GGP in China. After introducing the study area, and research methods and data used in this study in Section 3, Section 4 discusses the spatio-temporal patterns of cropland conversion in response to the GGP in Yanchuan County from the perspectives of slope gradient, physical quality, and accessibility. This paper ends with policy implications and recommendations.

\section{Background: The Progress of China's “Grain for Green Project"}

Responding to severe and prolonged droughts on the lower reaches of the Yellow River in 1997, and massive flooding on the Yangtze River in 1998, China's central government initiated the GGP in 1999, with a primary aim to reduce soil erosion from sloping cropland through transforming them into grassland or forest. After a three-year demonstration (1999-2001) in three ecologically fragile provinces (Sichuan Province in the upper reaches of the Yangtze River, Shaanxi Province, and Gansu Province in the upper reaches of the Yellow River), the GGP has been implemented on a large-scale (see Figure 1) since the beginning of 2002 .

Figure 1. The province-level regions involved in GGP and geographical context of Yanchuan County.

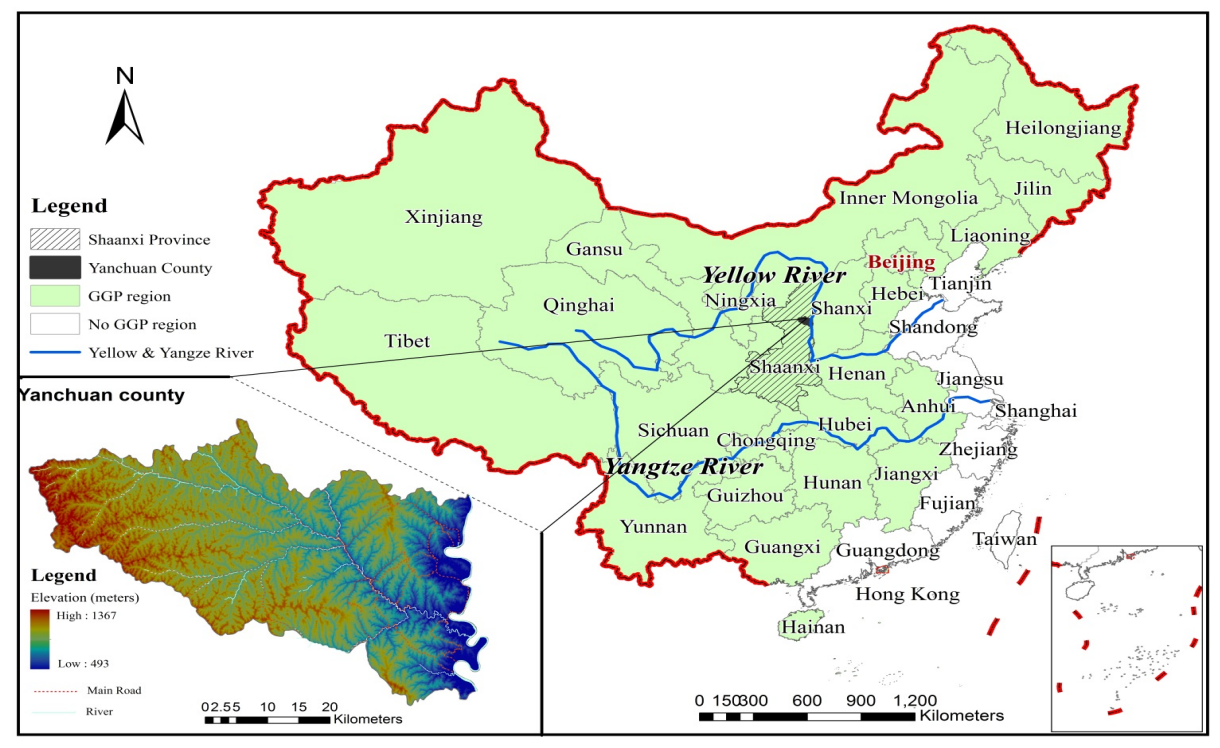

The land with a slope greater than 15 degrees in North China, or 25 degrees elsewhere, was encouraged to be converted to forest and grassland. The GGP planned to convert 14.7 million hectares of cropland on 
steep slopes in the upper reaches of the Yellow and Yangtze River Basins back to forest and into natural grassland. In addition, 17.3 million hectares of vegetative cover would be afforested by reclaiming suitable barren land [19]. Twenty-five provinces are now involved in the project, encompassing all of China with the exception of the densely populated and developed eastern regions (Figure 1).

In addition to ecological restoration, the project also intended to alleviate poverty and improve the productivity of agriculture, since the government has realized that the project would not make progress successfully without farmers' active engagement. The project took a top-down approach to selecting towns or villages as the targeted regions, namely, as the quotas of pending-cropland was allocated by the higher level government to lower level one. In addition, the project used a public payment scheme to subsidize millions of participating rural households. Farmers are core agents of project implementation, and they had partial right to select the sloping plots for converting guided by the officials of local Forestry Department [20].

For every hectare of converted sloping cropland, farmers were compensated with 2,250 kg of grain (in the upper reaches of the Yangtze River) or 1,500 kg of grain (in the Yellow River) every year and also RMB 75 per hectare for the purchase of tree seedlings. Additionally, the provincial governments also gave farmers RMB 300 (approximately US\$ 36) each year as basic living expense for every hectare [21]. After 2004, the compensation of grain was to be paid in cash at an average price of RMB 1.4 per kilogram of grain. Farmers were compensated for two years for grassland, five years for fruit tree plantations, and eight years for ecological forests.

Table 1. The structure of decreased cropland during 1999-2008 (unit: ha). Source: Ministry of Land and Resources (2010).

\begin{tabular}{cccccc}
\hline Year & $\begin{array}{c}\text { Decrease of } \\
\text { Cropland }\end{array}$ & $\begin{array}{c}\text { Land for } \\
\text { Construction Use }\end{array}$ & $\begin{array}{c}\text { Destroyed by } \\
\text { Natural Hazards }\end{array}$ & $\begin{array}{c}\text { Turned to } \\
\text { Ecological Uses }\end{array}$ & $\begin{array}{c}\text { Agricultural } \\
\text { Restructuring }\end{array}$ \\
\hline 1999 & $841,676.83$ & $205,258.45$ & $134,679.86$ & $394,614.36$ & $107,124.16$ \\
2000 & $1,566,042.89$ & $163,258.89$ & $61,738.17$ & $762,821.10$ & $578,224.74$ \\
2001 & $893,268.40$ & $163,653.95$ & $30,579.03$ & $590,689.27$ & $108,346.15$ \\
2002 & $2,027,400.29$ & $196,499.60$ & $56,338.65$ & $1,425,552.49$ & $349,009.55$ \\
2003 & $2,880,991.85$ & $229,105.72$ & $50,424.97$ & $2,237,309.07$ & $364,152.08$ \\
2004 & $1,478,320.69$ & $292,803.59$ & $63,283.37$ & $732,865.89$ & $389,367.84$ \\
2005 & $984,533.79$ & $212,111.54$ & $53,504.17$ & $390,321.87$ & $328,596.22$ \\
2006 & $1,026,585.45$ & $258,539.55$ & $35,863.67$ & $339,390.15$ & $392,792.09$ \\
2007 & $340,657.69$ & $188,285.96$ & $17,924.21$ & $25,445.76$ & $109,001.75$ \\
2008 & $278,012.46$ & $191,568.19$ & $24,803.18$ & $7,598.22$ & $54,042.87$ \\
Total & $12,317,490.34$ & $2,101,085.44$ & $529,139.27$ & $690,6608.18$ & $2,780,657.45$ \\
\hline
\end{tabular}

Although the GGP was initially planned to be finished by the end of 2010, the central government declared by the end of 2006 that no new regions could be approved to join in the project. The key task of the GGP shifted from sloping land conversion to barren land afforestation. The reason for this policy shift was that the large-scale implementation of the GGP had caused rapid cropland loss and to some extent threatened the food security of China. According to the land use statistical data (Table 1) [22], a total of over 6,906,608 ha of cropland were turned into ecological use between 1999 and 2006, accounting for $56.07 \%$ of the decrease in the total acreage of China's cropland. The GGP became a primary contributor to the rapid and massive loss of cropland in China. As shown in Table 1, cropland 
conversion for ecological uses reached its maximum, with over 2,237,000 ha (77.66\% of cropland loss) in 2003. Consequently, there has been a continuous decrease in grain production in China for five years since 1998. China's total grain production stood at its bottom, with 430 billion $\mathrm{kg}$ in 2003. Since 2007, balancing food security and ecology conservation has become an important issue of the GGP. One of the measures to ensure this is to limit the scale of the GGP, and another is to extend the government payment duration (based on the above mentioned three levels from 2007).

The Loess Plateau is a priority region for the GGP, not only because it is located in the upper and middle reaches of the Yellow River, but is also facing the serious problem of soil erosion and water loss $[11,23]$. In this paper we selected Yanchuan County, Shanxi Province, located on the Loess Plateau on the upper reaches of the Yellow River, as a case study to quantify and assess the cropland conversion in response to GGP.

\section{Study Area}

Yanchuan County is located in the central part of the Loess Plateau $\left(36^{\circ} 37^{\prime} 15^{\prime \prime} \mathrm{N}-37^{\circ} 5^{\prime} 55^{\prime \prime} \mathrm{N}\right.$, $109^{\circ} 36^{\prime} 20^{\prime \prime} \mathrm{E}-109^{\circ} 26^{\prime} 44^{\prime \prime} \mathrm{E}$ ) and on the west bank of the Yellow River (Figure 1), with an area of coverage of $1984 \mathrm{~km}^{2}$. The county has the typical hilly loess terrain of the Loess Plateau with varying altitudes between $493 \mathrm{~m}$ and $1,367 \mathrm{~m}$, and $48.25 \%$ of the territorial scope has a slope gradient of more than 15 degrees and $11.46 \%$ with slope of more than 25 degrees. Due to the steep terrains, most sloping cropland in the county is not suitable or marginally suitable for cropping. The county is located in a semi-arid zone with a mean annual precipitation of $500 \mathrm{~mm}$ and a mean temperature of 10.6 degrees Celsius. Before the GGP, the study area was largely covered with shrub-grasslands and slope croplands. Yanchuan County is historically and currently an agricultural area. As of the end of 2011, Yanchuan County, governing 14 towns, had a total population of 168,500 , approximately $80 \%$ of whom were engaged in agricultural production. In 1999, Yanchuan County took the lead in implementing the GGP due to its severe soil erosion and water loss, and the project covered 339 villages in all towns. According to the plan issued by the Yanchuan County Forestry Department, a local government agency in charge of GGP, 50,000 ha of croplands and degraded hillsides were to be converted into forestland.

\section{Data and Research Methods}

\subsection{Data Resources and Pre-Processing}

Detailed spatial data of cropland conversion need to be produced for this study. However, there is none available for the GGP by the local government and related institutions. We selected high-resolution remote sensing imagery as the basic data resource, and land use data, topographic maps, and socio-economic statistical data were also collected for further data processing.

As the GGP began in Yanchuan county in 1999, two historical Landsat satellite images (TM data taken on 17 October 1999, and ETM+ data 15 October 2011; (Path 127 (orbit), Row 34 (scene center)) were downloaded from the International Scientific Data Service Platform [24], and the Landsat ETM+ SLC-off image was processed with a self-adaptive local regression model for multi-temporal imagery [25]. All of the images were clear and nearly free of clouds (total cloud cover less than 5\%). October is the most indicative month in this area: cropland and new sparse forest can be easy to distinguish at this time, 
however the cropland in the late summer (August and September), especially planting maize, is often confused with shrubs. After the harvest season for crops, including maize, potato, and millet in the Loess Plateau (from the middle of September to the beginning of October), the cropland is covered by nothing but straw and has a regular shape, which help to distinguish it from sparse forest and other land uses. Consequently, the October images were employed.

In order to assist image interpretation, two land use maps were collected from Land and Resources Department of Yanchuan County. They were mapped by the two National Land Surveys, in 1996 and in 2008, respectively. The slope map was derived from ASTER Global Digital Elevation Model (ASTER GDEM) data which is acquired by a satellite-borne sensor "ASTER" to cover all the land on earth. It was downloaded from its official website [26]. In September 2012, a field survey, including 90 sampling-points, was carried out by using a global positioning system to identify present land-use types and trace land-use histories. These points were evenly distributed in the study area, and at the same time land-use types and transportation accessibility were taken into consideration.

Fifteen well distributed ground control points (GCPs) were selected for geometric correction of remote sensing imagery according to the Second Land Survey map. Two images were geo-referenced to the Xi'an 1980 Coordinate System. The root mean square error (RMSE) was less than 1 pixel. A first order polynomial fit was applied and all the data were re-sampled to a spatial resolution of $30 \mathrm{~m}$ using nearest neighbor method. In order to improve the visual interpretability of images, a color composite (Landsat TM Bands 4, 5, and 3) was prepared and its contrast was stretched using the Gaussian distribution function. The $3 \times 3$ high pass filters were applied to the color composite to further enhance visual interpretation of linear features, e.g., rivers and vegetation features.

\subsection{Methods}

\subsubsection{Land Use/Cover Information}

In order to detail the land use/cover changes, land use/cover was classified into eight types: cropland, orchard, closed forest, sparse forest, grassland, waterbody, residential land, and unused land (see Table 2). The more accurate classification system helps to reveal the essential influence of the GGP on cropland conversion, because it distinguishes different kinds of forests (closed forest, sparse forest, and orchard). The training areas were established according to more than 90 field-sampling points and the two National Land Use Surveys maps by the software Erdas 9.0. Then, the two images were interpreted by the method of supervised classification using Maximum Likelihood Classifier (MLC), visual interpretation

involved the use of image characteristics such as texture, pattern, and color to translate image into land use. A $3 \times 3$ majority-neighborhood filter was used to adjust the classified images.

To assess the accuracy of the land/cover maps, 310 and 324 reference pixels were created from the respective 2011 and 1999 map classes in a well distributed manner [27]. For the 2011 land/cover validation, the reference pixels were derived from two datasets: 90 ground locations were visited in September 2012, and 234 reference pixels were examined through visual interpretation of Google Earth images (high resolution images in 2013). For the 2009 land/cover validation, 28 unchanged ground locations were also used in this process, and 282 reference pixels came from the land use map at a 1:50,000 scale that produced by the First National Land Survey in 1996. The confusion matrix of the 2011 classified image shows an overall accuracy of $76.7 \%$ and a Kappa index agreement of 0.76 (Table 3 ). 
For the 1999 land use/cover map, the values of the confusion matrix indicate an overall accuracy of $77.1 \%$ and a Kappa index agreement of 0.76 (Table 4). In addition, the imagery data of the totals of converted cropland substantially matches with the official statistical data: according to the Report of Grain for Green Project of Yanchuan County, issued by local forestry government agency, 31,713.33 ha cropland was converted [28], while the total of converted cropland derived from the imagery was $30,156.05$ ha. The gap between the data derived from the Landsat imagery and the official statistical figure $(1,557.28 \mathrm{ha})$ is probably because a few trees exists in this area.

Table 2. Land use/cover classification in Yanchuan County.

\begin{tabular}{|c|c|}
\hline Classification & General Description \\
\hline \multirow{2}{*}{ Cropland } & The land planted for crops, including paddy field, irrigated land, and dry land. \\
\hline & Most croplands, slope of over $15^{\circ}$, is not or only marginally suitable for cultivation. \\
\hline \multirow{2}{*}{ Orchard } & The land grows economic perennial trees including fruit, tea-garden, and others. \\
\hline & The primary orchards in Yanchuan county are jujube and apple trees. \\
\hline Closed forest & Lands covered by natural or planted forests with a canopy density of over $30 \%$. \\
\hline \multirow{2}{*}{ Sparse forest } & Lands covered by natural or newly forested or shrub with a canopy density \\
\hline & between $10 \%$ and $30 \%$, they are almost newly afforested in the last decade. \\
\hline Grassland & $\begin{array}{l}\text { Lands mainly covered by herbaceous plant, including natural pasture, sown pasture, } \\
\text { and sparse shrubs with a canopy density of less than } 10 \% \text {. }\end{array}$ \\
\hline Waterbody & Reservoirs and ponds, rivers, and flooded lands. \\
\hline Residential land & Land used for townships and rural settlements, also including industrial sites and mining \\
\hline Unused land & Land refers to the area that is not put into practical use or difficult to use \\
\hline
\end{tabular}

\subsubsection{Land Use/Cover Change Matrix}

A land use/cover change matrix reveals the internal variations of land use changes during the study period, showing the detailed information on cropland conversions. The transition matrix of land use/cover was conducted through the spatial overlay of the two-phase land use maps interpreted from Landsat data.

\subsubsection{Structural Metrics of Landscape}

Landscape metrics are used to describe the structural characteristics of the landscape. Six indexes of landscape metrics were calculated by software FRAGSTATS 3.3 [29], including patch number (PN), patch density (PD), largest patch index (LPI), landscape shape index (LSI), Aggregation Index (AI), and Shannon's Diversity Index (SHDI). PD equals the number of a particular patch type (or class) per 100 ha, which is an indicator for fragmentation. LPI quantifies the percentage of total land area comprised by the largest patch of a land use class and is used to indicate the maximal land-use patch overall dominance degree. LSI equals the ratio of sum of edge lengths to total area of a land use class measured against a circle standard, and measures the shape configuration. AI is calculated from a patch adjacency matrix. These two metrics can be applied to indicate aggregation. SHDI is determined by both the number of different patch types and the proportional distribution of area among patch types and a measure of patch diversity in a landscape. By detecting the changes of landscape metrics, it can help in examining the changes in land use/cover patterns. 
Table 3. Confusion matrix of the 2011 classified image of Yanchuan County.

\begin{tabular}{|c|c|c|c|c|c|c|c|c|c|c|}
\hline \multirow{2}{*}{ Classification } & \multicolumn{10}{|c|}{ Ground data } \\
\hline & Cropland & Orchard Land & Closed Forest & Grassland & Residential Land & WaterBody & Sparsed Land & Unused Land & Total & Producer's Accuracy \\
\hline Cropland & 45 & 2 & 0 & 2 & 0 & 0 & 5 & 2 & 56 & $80.4 \%$ \\
\hline Orchard land & 3 & 40 & 6 & 0 & 0 & 0 & 3 & 0 & 52 & $76.9 \%$ \\
\hline Closed forest & 1 & 5 & 38 & 0 & 0 & 0 & 2 & 1 & 47 & $80.9 \%$ \\
\hline Grassland & 3 & 0 & 0 & 31 & 3 & 0 & 5 & 0 & 42 & $73.8 \%$ \\
\hline Residential land & 2 & 1 & 0 & 0 & 22 & 0 & 0 & 0 & 25 & $88.0 \%$ \\
\hline Waterbody & 0 & 0 & 0 & 0 & 0 & 20 & 0 & 3 & 23 & $87.0 \%$ \\
\hline Sparse land & 5 & 2 & 4 & 0 & 0 & 0 & 45 & 2 & 58 & $77.6 \%$ \\
\hline Unused land & 2 & 0 & 0 & 0 & 0 & 2 & 0 & 15 & 19 & $78.9 \%$ \\
\hline Total & 61 & 52 & 48 & 33 & 25 & 22 & 60 & 23 & 324 & \\
\hline User's accuracy & $73.8 \%$ & $76.9 \%$ & $79.2 \%$ & $93.9 \%$ & $88.0 \%$ & $90.9 \%$ & $75.0 \%$ & $65.2 \%$ & & \\
\hline
\end{tabular}

Overall accuracy: $76.7 \% ;$ Kappa $=0.76$.

Table 4. Confusion matrix for the 1999 classified image of Yanchuan County.

\begin{tabular}{|c|c|c|c|c|c|c|c|c|c|c|}
\hline \multirow{2}{*}{ Classification } & \multicolumn{10}{|c|}{ Ground data } \\
\hline & Cropland & Orchard Land & Closed Forest & Grassland & Residential Land & WaterBody & Sparsed Land & Unused Land & Total & Producer's Accuracy \\
\hline Cropland & 52 & 7 & 0 & 0 & 1 & 2 & 6 & 2 & 70 & $74.3 \%$ \\
\hline Orchard land & 2 & 32 & 7 & 1 & 0 & 0 & 2 & 0 & 44 & $72.7 \%$ \\
\hline Closed forest & 0 & 2 & 30 & 0 & 0 & 0 & 4 & 0 & 36 & $83.3 \%$ \\
\hline Grassland & 1 & 0 & 0 & 28 & 0 & 0 & 6 & 2 & 37 & $75.7 \%$ \\
\hline Residential land & 0 & 2 & 0 & 0 & 18 & 0 & 0 & 0 & 20 & $90.0 \%$ \\
\hline Waterbody & 0 & 0 & 0 & 0 & 0 & 22 & 0 & 4 & 26 & $84.6 \%$ \\
\hline Sparse land & 7 & 4 & 0 & 2 & 0 & 0 & 45 & 0 & 58 & $77.6 \%$ \\
\hline Unused land & 3 & 0 & 0 & 2 & 2 & 0 & 0 & 12 & 19 & $63.2 \%$ \\
\hline Total & 65 & 47 & 37 & 33 & 21 & 24 & 63 & 20 & 310 & \\
\hline User accuracy & $80.0 \%$ & $68.1 \%$ & $81.1 \%$ & $84.8 \%$ & $85.7 \%$ & $91.7 \%$ & $71.4 \%$ & $60.0 \%$ & & \\
\hline
\end{tabular}

Overall accuracy: $77.1 \% ;$ Kappa $=0.74$. 


\subsubsection{Calculating the Slope Gradient of Converted Cropland}

In order to explore the patterns of cropland conversion, we intended to calculate the slope gradient of converted cropland by the GIS. Based on 30m DEM data, the map of the terrain slope of the study area was generated using the Spatial Analyst of ArcGis software. The slope-values were reclassified into four levels in the map by the thresholds of $2^{\circ}, 6^{\circ}, 15^{\circ}$, and $25^{\circ}$, and the coverage of converted cropland with different slope grades was identified. The threshold selection refers to Technical Regulations on Land Use Survey formulated by Committee on Agricultural Regionalization of China. These regulations stipulate that there should be no soil erosion with $\leq 2$ it, slight erosion with $2^{\circ} \sim 6^{\circ}$, moderate erosion with $6^{\circ} \sim 15^{\circ}$, and serious erosion with $15^{\circ} \sim 25^{\circ}$. Croplands with a slope more than $25^{\circ}$ are forbidden to be cultivated [30]. In addition, we then calculated the area of converted cropland with different slope gradients by overlying the terrain slope map with the cropland conversion map.

\subsubsection{Grading Physical Quality of Converted Cropland}

For the purpose of identifying the physical quality of cropland that has been converted, we assessed the grade of converted cropland, based on the official data of the Assessment on Cropland Gradation of Yanchuan County. The assessment was sponsored by Ministry of Land and Resources of China and finished in 2009. The central government spent about RMB 120 million Yuan and eight years on assessing the cropland gradation of all counties in China, with the aim to provide the basis for cropland quality management, and compensation on cropland acquisition.

According to the Regulation on Cropland Gradation [31] formulated by China's Ministry of Land and Resources, Yanchuan's cropland regions were divided into 856 evaluation units, and spring maize and millet were selected as the appointed crops. By calculating the suitable values of cropland to appointed crops and its light-temperature potential productivity, the physical quality of Yanchuan's cropland was graded into five different levels [32]. Then, we summarized the area of converted cropland of five levels through overlying the cropland gradation map and the cropland conversion map.

\subsubsection{Buffer Analysis for the Spatial Distribution of Cropland Conversion}

In the Loess hilly areas, like in many other hilly regions in the world, accessibility has a great influence on land use/cover changes $[33,34]$. In order to examine the accessibility effect on the spatial distribution of cropland conversion, we performed buffer analysis of converted land to the main roads at equal intervals. There are some reasons why road accessibility was used in this case as a key parameter. Firstly, according to the mapping result of land use/cover change, we found that cropland near the main roads changed more obviously (see Section 5.5). Secondly, we knew from personal interviews with local farmer that they preferred to convert the cropland near main roads for its convenient management (also see Section 5.5). Finally, and most importantly, the main roads (highway, national, provincial, and county roads) in the hilly areas parallel the rivers (streams, irrigations) and run in a continuous and regular manner (see Figure 1 and Figure 2), meaning their effects of main roads on GGP would be similar with that of the rivers. Thus, the main roads are conducive to buffer analysis. Five buffer-zones along the main roads were built at an interval of $0.5 \mathrm{~km}$ and were used to examine the characteristics of spatial distribution of cropland conversion with reference to its accessibility. 
Figure 2. Geographical distributions of land use/cover in Yanchuan County. (a) Land use/cover in 1999; (b) Land use/cover in 2011; (c) main land use/cover changes; (d) A part of main land use/cover changes.
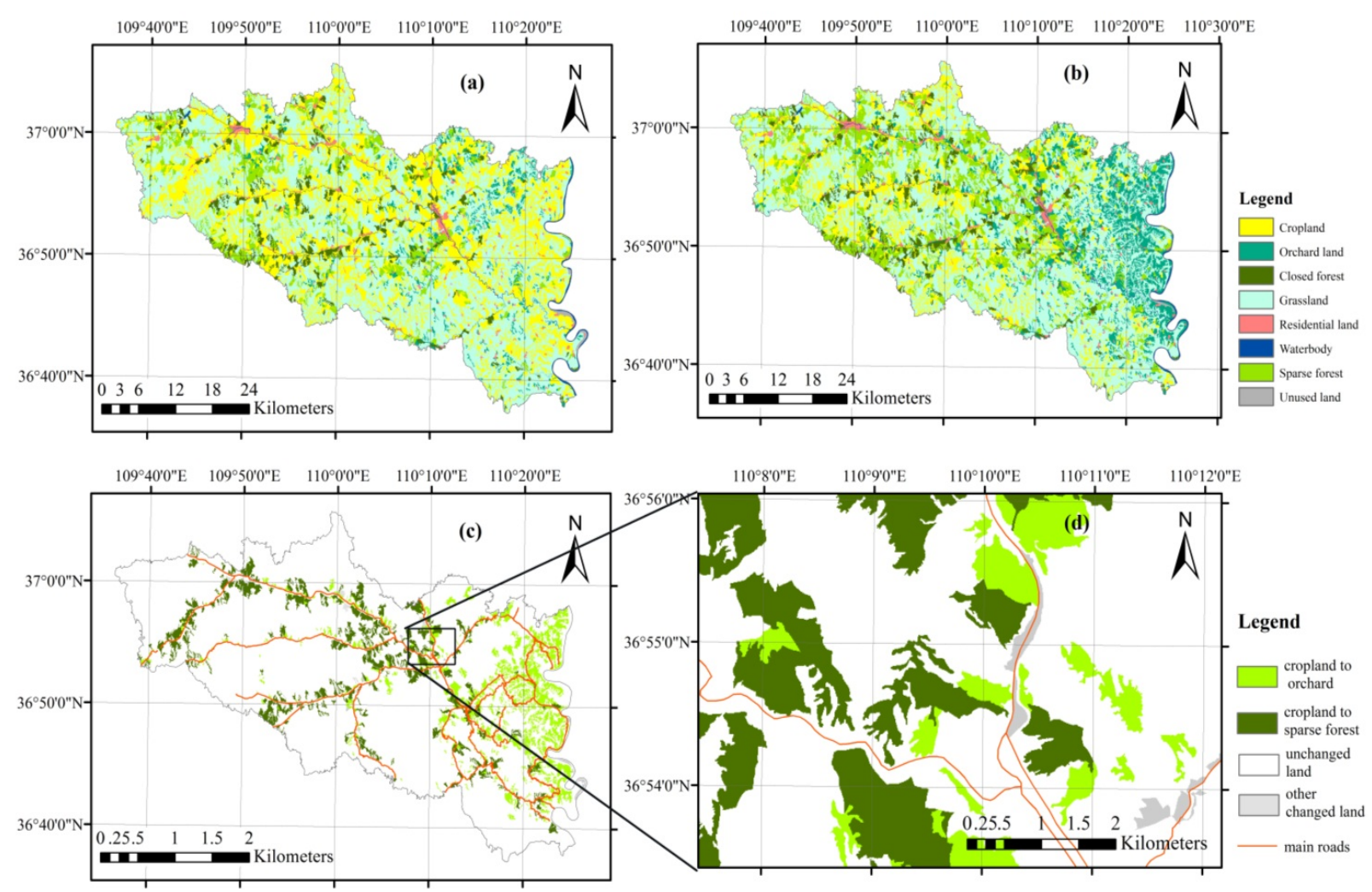

\subsubsection{Personal Interviews with Local Farmers and Government Officials}

In order to better understand the underlying mechanisms of cropland conversion, 36 semi-structured interviews were conducted in September 2012, with 24 farmers, eight village heads, two township heads, the director of the Forestry Department, and the director of the GGP workgroup of Yanchuan County. The interviews with local farmers were used to investigate their personal views on what kinds of cropland were converted and what kinds of afforestation were converted to, where the converted cropland is located, and the reasons behind their selections, while the interviews with local governments officials was to understand the profiles of the GGP in this region, and challenges they were facing to further consolidate the achievements of the GGP.

\section{Results}

\subsection{Analysis of Overall Land Use/Cover Change}

Table 5 and Figure 2 offer the profile and geographical patterns of land use/cover change in Yanchuan County, showing the land use/cover has been changed drastically after the GGP. Cropland was $65,419.54$ ha, accounting for $33.0 \%$ of total area before the implementation of GGP in 1999 . However, only $34,145.14$ ha cropland (17.2\% of total land area) remained in 2011 . In contrast, orchard land and sparse forest increased significantly during the time period (1999-2011): the former increased 
from $6,748.69$ ha $(3.4 \%$ of total land area) to $24,082.79$ ha $(12.1 \%)$ and the latter was raised from $12,632.24$ ha $(6.4 \%$ of total land area) to $26,990.98$ ha $(13.6 \%)$.

The transition matrix of land use/cover conversion (Table 5) reveals that the cropland decreased primarily due to its conversion to orchard land and sparse forest, where $15,598.87$ ha (23.84\% of total cropland) was converted into orchard land and $14,557.18$ ha (22.25\% of total cropland) was converted into sparse forest. In other words, the increases of orchard land and sparse forest were almost all converted from cropland. Precisely speaking, $64.78 \%$ of total orchard land and $53.93 \%$ of total sparse forest in 2011 came from cropland. During the GGP, farmers also converted cropland to 232.72 ha of grassland and 1,324.51 ha orchard land respectively, and 637.62 ha grassland was changed into sparse land. Note that 208.07 ha cropland and 68.21 ha orchard land was converted to residential land during 1999-2011, mainly around large towns. There were other small conversions in the matrix, but they were inconspicuous to the overall changes.

Table 5. Matrix of land use/cover changes during 1999-2011 (unit: ha).

\begin{tabular}{cccccccccc}
\hline \multirow{2}{*}{$\begin{array}{c}\text { Land Use } \\
\text { Types in 1999 }\end{array}$} & Cropland & $\begin{array}{c}\text { Orchard } \\
\text { Land }\end{array}$ & $\begin{array}{c}\text { Closed } \\
\text { Forest }\end{array}$ & Grassland & $\begin{array}{c}\text { Residential } \\
\text { Land }\end{array}$ & Waterbody & $\begin{array}{c}\text { Sparse } \\
\text { Land }\end{array}$ & $\begin{array}{c}\text { Unused } \\
\text { Land }\end{array}$ & Total \\
\hline Cropland & $33,826.87$ & $15,598.87$ & 0.00 & $1,228.55$ & 208.07 & 0.00 & $14,557.18$ & 0.00 & $65,419.54$ \\
Orchard land & 63.20 & $6,532.07$ & 0.00 & 0.00 & 68.21 & 0.00 & 85.21 & 0.00 & $6,748.69$ \\
Closed forest & 0.00 & 182.32 & 7980.32 & 0.00 & 0.00 & 0.00 & 55.87 & 0.00 & $8,218.51$ \\
Grassland & 232.72 & $1,324.51$ & 0.00 & $96,556.61$ & 0.00 & 0.00 & 637.62 & 0.00 & $98,751.46$ \\
Residential land & 0.00 & 0.00 & 0.00 & 0.00 & $4,026.51$ & 0.00 & 0.00 & 0.00 & $4,026.51$ \\
Waterbody & 0.00 & 0.00 & 0.00 & 0.00 & 0.00 & $2,144.15$ & 0.00 & 0.00 & $2,144.15$ \\
Sparse land & 22.35 & 185.56 & 295.95 & 473.28 & 0.00 & 0.00 & $11,655.10$ & 0.00 & $12,632.24$ \\
Unused land & 0.00 & 259.46 & 0.00 & 6.60 & 0.00 & 0.00 & 0.00 & 211.96 & 478.02 \\
Total & $34,145.14$ & $24,082.79$ & 8276.27 & $98,265.04$ & $4,302.79$ & $2,144.15$ & $26,990.98$ & 211.96 & $198,419.12$ \\
\hline
\end{tabular}

Through our field investigations and interviews with farmers, we found that the orchard land converted from cropland were largely for growing apple, jujube and peach trees, since farmers were encouraged to plant economic fruit trees by the GGP. Sparse forest is newly afforested Platycladus Orientalis and Chinese Pine, as these saplings were provided by the local GGP institution. This implies that the GGP is not only a large afforestation project, but also an action for rural poverty alleviation as the central government stated that the farmers' benefits should be ensured during the implementation of GGP. In addition, China's farmers own the contractual management right of the sloping cropland. Thus, the farmers often made the final decision as to whether the sloping cropland should be converted into orchard or ecological forest. As orchard land could generate more economic benefit, the local farmers often gave preference to convert sloping cropland to orchard. Consequently, the sloping cropland has mostly been converted into orchard land in this county.

\subsection{Dynamics of Landscape Metrics}

The landscape characteristics in Yanchuan County changed significantly between 1999 and 2011 (Table 6). The total number of patches and path density clearly increased, indicating that the whole landscape is more fragmented than before. Meanwhile, Shannon's diversity index increased from 1.278 
to 1.444 and $\mathrm{AI}$ index decreased by 0.57 , which suggests that the richness and evenness of the whole landscape has increased.

Table 6. Landscape metrics and its change in Yanchuan County.

\begin{tabular}{|c|c|c|c|c|c|c|c|}
\hline Land & Year & PN & PD & LPI & LSI & AI & SHDI \\
\hline \multirow{3}{*}{ Cropland } & 1999 & 1060 & 0.534 & 1.744 & 119.442 & 95.367 & \\
\hline & 2011 & 1109 & 0.559 & 0.683 & 116.121 & 93.827 & \\
\hline & change & 49 & 0.025 & -1.061 & -3.320 & -1.540 & \\
\hline \multirow{3}{*}{ Orchard } & 1999 & 512 & 0.258 & 0.093 & 60.043 & 92.800 & \\
\hline & 2011 & 958 & 0.483 & 1.014 & 85.951 & 94.345 & \\
\hline & change & 446 & 0.225 & 0.921 & 25.908 & 1.545 & \\
\hline \multirow{3}{*}{ Closed forest } & 1999 & 192 & 0.097 & 0.089 & 41.422 & 95.534 & \\
\hline & 2011 & 195 & 0.098 & 0.103 & 41.514 & 95.603 & \\
\hline & change & 3 & 0.002 & 0.014 & 0.092 & 0.069 & \\
\hline \multirow{3}{*}{ Grassland } & 1999 & 380 & 0.192 & 14.707 & 109.833 & 96.536 & \\
\hline & 2011 & 378 & 0.191 & 14.744 & 109.845 & 96.539 & \\
\hline & change & -2 & -0.001 & 0.037 & 0.013 & 0.003 & \\
\hline \multirow{3}{*}{ Residential land } & 1999 & 313 & 0.158 & 0.107 & 41.576 & 93.591 & \\
\hline & 2011 & 314 & 0.158 & 0.114 & 41.813 & 93.716 & \\
\hline & change & 1 & 0.001 & 0.007 & 0.238 & 0.125 & \\
\hline \multirow{3}{*}{ Waterbody } & 1999 & 43 & 0.022 & 0.889 & 50.022 & 89.380 & \\
\hline & 2011 & 43 & 0.022 & 0.889 & 50.022 & 89.380 & \\
\hline & change & 0 & 0.000 & 0.000 & 0.000 & 0.000 & \\
\hline \multirow{3}{*}{ Sparse land } & 1999 & 242 & 0.122 & 0.313 & 47.881 & 95.825 & \\
\hline & 2011 & 425 & 0.214 & 0.375 & 66.195 & 96.022 & \\
\hline & change & 183 & 0.092 & 0.062 & 18.314 & 0.197 & \\
\hline \multirow{3}{*}{ Unused land } & 1999 & 17 & 0.009 & 0.101 & 9.073 & 96.284 & \\
\hline & 2011 & 15 & 0.008 & 0.064 & 9.127 & 94.363 & \\
\hline & change & -2 & -0.001 & -0.037 & 0.054 & -1.921 & \\
\hline \multirow{3}{*}{ Whole landscape } & 1999 & 2759 & 1.391 & 14.707 & 96.137 & 96.133 & 1.278 \\
\hline & 2011 & 3437 & 1.732 & 14.744 & 101.441 & 95.563 & 1.444 \\
\hline & change & 678 & 0.342 & 0.037 & 5.304 & -0.570 & 0.166 \\
\hline
\end{tabular}

Note: $P N$ numbers of patches, $P D$ patch density, $L P I$ largest patch index, $L S I$ landscape shape index, $A I$ aggregation index, SHDI Shannon's diversity index.

The changes in class-level landscape varied with land use/cover types. The PN of cropland increased from 1,060 to 1,109 , and the PD increased from 0.534 to 0.559 . Meanwhile, the LPI, LSI, and AI decreased by the value of 1.061, 3.320, and 1.540, respectively. It is verified that cropland has become more fragmented than before. The PN, PD, and LPI of orchard have increased, and the paths of orchard have become more dominant than before. The LSI and AI of orchard land have increased remarkably, indicating that its patches became more spatially aggregated. According to Table 5, the landscape characteristics of sparse forest had the similar change with that of orchards, and its patterns were obviously modified by the GGP. In short, after the implementation of the GGP, orchard and sparse forest have become more dominant, whereas there were very few changes in the landscape metrics of other land use types.

According to the above analysis, the indexes of cropland, orchard, and sparse land changed significantly but the other with small changes, these changes indicated that a more fragmented but also 
diversified landscape was caused to a great degree by the implementation of the GGP. In addition, the farms were equally allocated to farmers under the household contract responsibility system in rural areas [35]. Accordingly, the geographical size of farms did not change considerably. However, fragmentation of agricultural landscapes may landscape diversity and also more diverse habitats, which is of much importance to the whole ecological system, but it potentially lead to increased costs of production and reduce the farmers' enthusiasm to participate in GGP.

\subsection{Cropland Conversion on Different Slope Gradients}

We calculated the area of converted cropland on different slope gradients, and the overall result indicated that $1,783.51$ ha $(5.27 \%$ of total converted cropland) was distributed on the slope gradient of less than $6^{\circ}, 11,346.05$ ha $(33.54 \%)$ on slopes between $6^{\circ}$ and $15^{\circ}, 12,213.23$ ha $(36.11 \%)$ on slope gradients between $15^{\circ}$, and $25^{\circ}, 6,041.81$ ha $(17.86 \%)$ on slopes of more than $25^{\circ}$. In terms of different slope gradients, $44.57 \%$ of the sloping cropland (with slope between $6^{\circ}$ and $15^{\circ}$ ), $48.87 \%$ (with slope between $15^{\circ}$ and $25^{\circ}$ ), and $70.78 \%$ (more than 25 degrees) were converted.

To further analyze the concrete patterns of cropland conversion, three main types of conversion have been calculated (see Figure 3). Firstly, 8,457.55 ha (54.22\% of the total area of cropland converted into orchard) were distributed on slopes between $6^{\circ}$ and $15^{\circ}$, and 5,080.78 ha (32.57\%) on slopes between $15^{\circ}$ and $25^{\circ}$. They together accounted for $86.79 \%$ of total cropland (with the slope between $6^{\circ}$ and $25^{\circ}$ ). Secondly, the area of cropland converted into to sparse forest was mostly distributed on slopes of more than $15^{\circ}$, with 6751.99 ha $(46.38 \%$ of the converted cropland for sparse forest) on slope gradients between $15^{\circ}$ and $25^{\circ}$, and 4920.24 ha $(38.80 \%)$ on slope gradients of more than $25^{\circ}$. Thirdly, the area of cropland converted into grassland was only $3.92 \%$ of the converted cropland, and it was distributed evenly on slopes with more than $6^{\circ}$.

Figure 3. Distribution of converted cropland on different gradients in Yanchuan County.

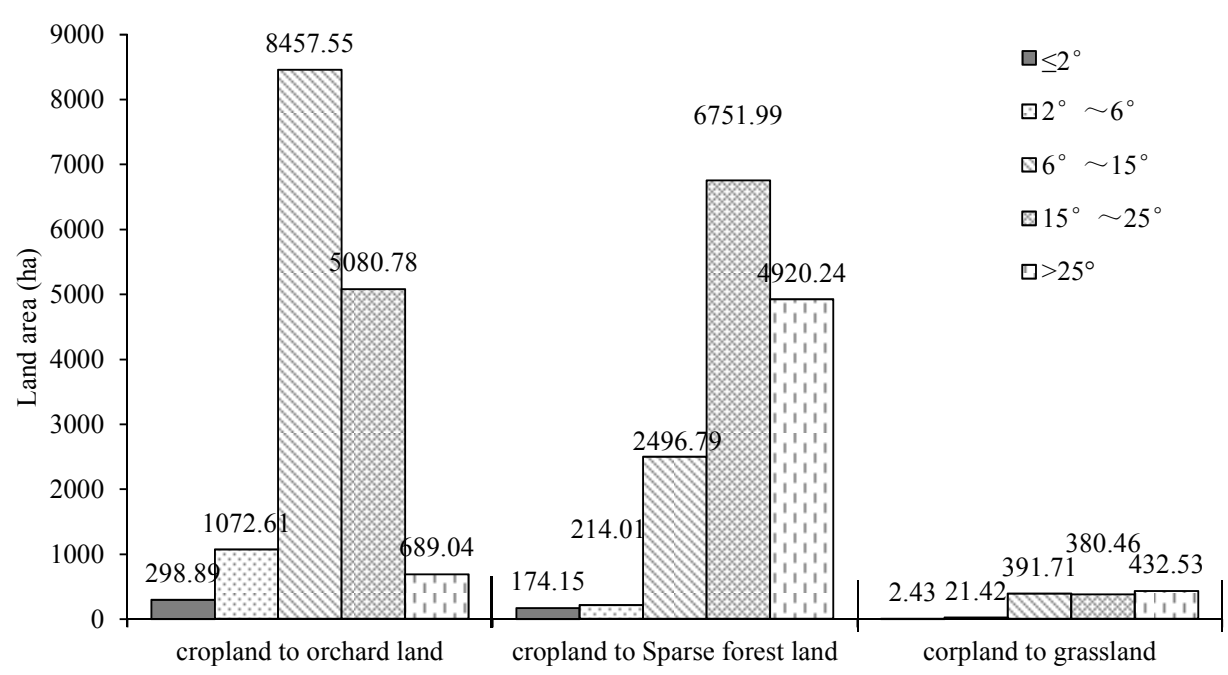

Note that $38.81 \%$ of the total croplands distributed on the slope less than 15 degrees were returned (see Figure 3), which was inconsistent with the original GGP requirements of the central government. This reflects that the GGP was a large afforestation project for the national and state governments, but for local farmers, it was a means to alleviate poverty. To adjust the agricultural structure and enhance the 
economic income, many households planted jujube and apple trees on the suitable cropland with a slope less than $15^{\circ}$, but they also regarded their work as a part of the GGP. Through participation in GGP, these households got subsidies from the government according to the regulation of GGP, increased their income from selling fruits. This could explain why $38.81 \%$ of the total converted land was distributed on slope gradients less than $15^{\circ}$. Our interviews with local farmers confirmed that the households preferred to convert suitable cropland to orchard, and preferred to convert the infertile sloping cropland without irrigation and field road to planting Platycladus Orientalis and Chinese Pine.

\subsection{Grading Physical Quality of Converted Cropland}

Based on the official data from the Assessment on Cropland Gradation of Yanchuan County, the physical quality of converted cropland was identified. As Figure 4 shows, in general, the returned cropland was mostly the lower grade land (the fifth and fourth grade), whereas the higher-grade cropland (the top and second grade) was largely not changed, and merely a small amount of higher-grade cropland was converted into orchard. Specifically, $89.39 \%$ of the fifth grade cropland (11,088.66 ha) was returned, $63.72 \%$ of which was converted into sparse forest; $61.98 \%$ of the fourth grade cropland $(5,836.62$ ha) was returned, $32.75 \%$ of which was converted into orchard and $26.02 \%$ into sparse forest. In total, $64.85 \%(20,354.13 \mathrm{ha})$ of total converted cropland is lower-grade and $16.55 \%(5,193.85 \mathrm{ha})$ of total converted cropland is higher-grade.

Figure 4. Distribution of converted cropland by different grades of physical quality.

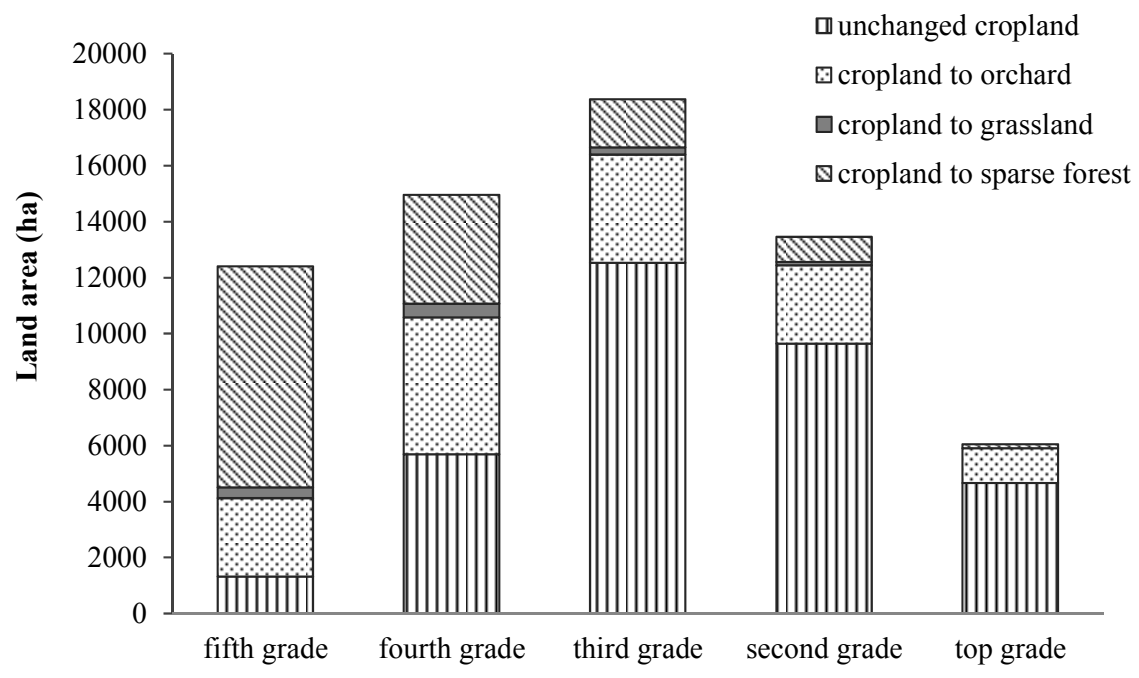

\subsection{Cropland Conversion in Each Buffer-Belt Referring to the Main Roads}

By using the buffer analysis method, we identified the distribution of converted cropland in different buffer-belts referring to the main roads. As shown in Figure 5, there were 10,931.28 ha (34.83\%) of total converted cropland in the $0-0.5 \mathrm{~km}$ buffer, and $65.48 \%$ of cropland in this buffer was changed. 8,662.95 ha (27.60\%) of total converted cropland in the $0.5-1.0 \mathrm{~km}$ buffer, $69.64 \%$ of which was changed. $5,106.55$ ha (16.27\%) of total converted cropland in the $1.0-1.5 \mathrm{~km}$ buffer, and $57.21 \%$ of cropland in this buffer was changed. In total, $78.70 \%$ of converted cropland was distributed in the $0-1.5 \mathrm{~km}$ buffers (see Table 7). Afterwards, we depicted the structure of converted cropland in each belt. Cropland to orchard was more 
popular than the other two conversions in the $0-0.5 \mathrm{~km}$ belt. However, cropland to sparse forest was the dominating conversion in other belts (Figure 5). These results indicated that cropland converted to forestland was often located in the more accessible areas, nearby main roads.

Figure 5. Distribution of converted cropland in each buffered belt referring to the main roads.

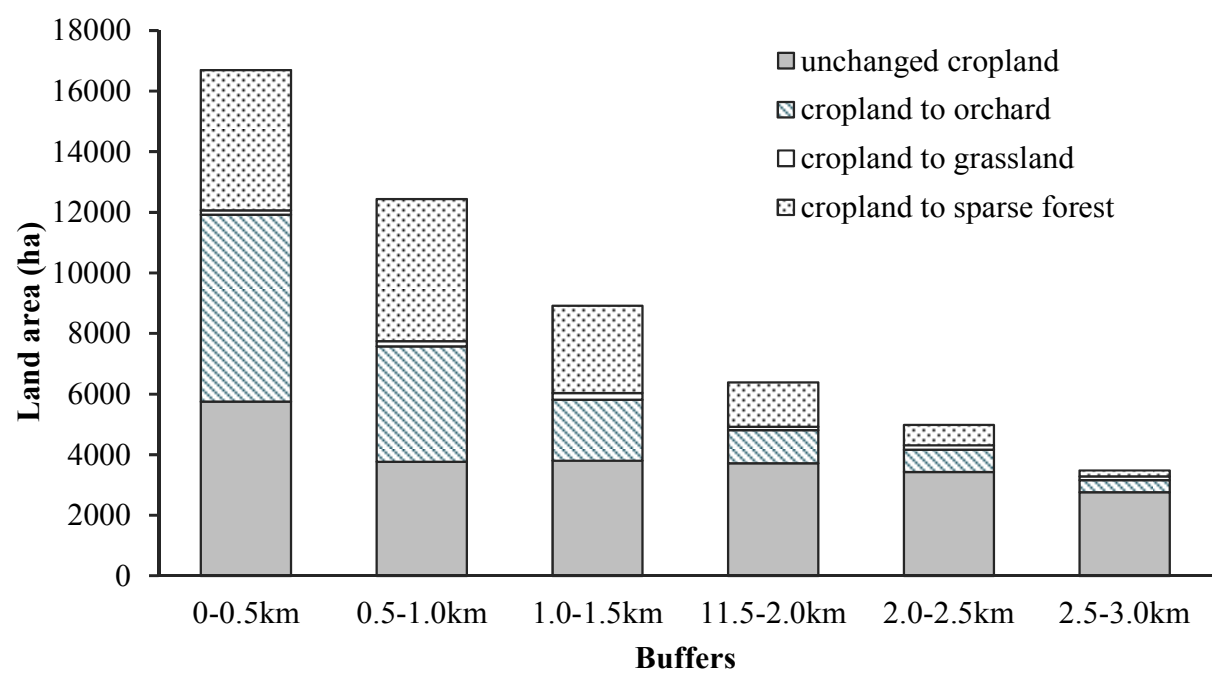

Table 7. The area of converted cropland in each belt referring to the main roads.

\begin{tabular}{ccccccc}
\hline Buffers & $\mathbf{0 - 0 . 5} \mathbf{~ k m}$ & $\mathbf{0 . 5}-\mathbf{1 . 0} \mathbf{~ k m}$ & $\mathbf{1 . 0}-\mathbf{1 . 5} \mathbf{~ k m}$ & $\mathbf{1 1 . 5 - 2 . 0} \mathbf{~ k m}$ & $\mathbf{2 . 0}-\mathbf{2 . 5} \mathbf{~ k m}$ & $\mathbf{2 . 5}-\mathbf{3 . 0} \mathbf{~ k m}$ \\
\hline unchanged cropland & $5,761.85$ & $3,776.44$ & $3,818.93$ & $3,724.92$ & $3,446.57$ & $2,775.95$ \\
cropland to orchard & $6,159.46$ & $3,806.05$ & $2,006.15$ & $1,091.69$ & 726.29 & 397.03 \\
cropland to grassland & 155.61 & 174.87 & 221.85 & 116.75 & 151.41 & 118.06 \\
cropland to sparse forest & $4,616.21$ & $4,682.03$ & $2,878.55$ & $1,465.64$ & 666.31 & 201.61 \\
$\begin{array}{c}\text { total converted cropland } \\
\text { total cropland in belts }\end{array}$ & $10,931.28$ & $8,662.95$ & $5,106.55$ & $2,674.08$ & $1,544.01$ & 716.7 \\
$\begin{array}{c}\text { percentage of converted } \\
\text { cropland in total cropland } \\
\text { percentage of cropland in } \\
\text { total land }\end{array}$ & 34.693 .13 & $12,439.39$ & $8,925.48$ & 6,399 & $4,990.58$ & $3,492.65$ \\
\hline
\end{tabular}

In order to understand this phenomenon, we made in-depth interviews with farmers living in different belts and also with local officials in charge of GGP. The reasons can be summarized as follows. Firstly, the households would more like to convert the sloping cropland to orchard with convenient transportation, because being located in the more accessible areas makes it more convenient to manage fruit trees and transport the products. Secondly, as the newly planted trees were easily irrigated through the convenient infrastructural lines, their survival rate was higher. Last, but not least, the local government officials in charge of the GGP set an "informal" principle that sloping cropland close to main roads, especially on both sides of the highway and national roads, should be given priority to conversion, as they insisted that this is good to display their GGP policy implementation achievements to high-level government officials who inspected this project. 


\section{Discussions}

From the above analyses, we can find that, though the central and local governments are of much importance to the success of GGP, namely, plan making, process management, financial supporting and others. However, we strongly argue that local farmers, as the core agents in the GGP together with local government officials, have a greater influence in determining what kinds of cropland were converted to which kinds of forest. Local farmers attempted to meet the national ecological target, and, simultaneously, to maximize their own incomes. Farmers often preferred converting sloping cropland to orchard because orchards generated more income than ecological forest and grass. Indeed, both perceived benefits (less erosion) and perceived harm (community economy, weeds, and land rental availability) are equally important to affect the attitudes of local agricultural producers to the large-scale state environment programs, including the Conservation Reserve Program (CRP) of the USA [36]. According to our household surveys, about RMB 5,000 per mu $(1 \mathrm{mu}=0.067 \mathrm{ha})$ would be produced from the conversion from cropland to orchard, while only about RMB 300 per mu from conversion to ecological forest. When the farmer owns $1 \mathrm{mu}$ sloping cropland, they can gain an RMB 85.84 agricultural subsidy from the government. Along with the increasing crop price, farmers were disinclined to convert sloping cropland to ecological forest on a large scale. This is one of the huge challenges to the long-term sustainability of the GGP.

In addition, the GGP will be confronted with troublesome issues, as in other conservation programs, in which converted cropland is expected to return to crop production following the expiration of the GGP. For example, the Conservation Reserve Program (CRP) in United States was initiated in 1980s with most of the first CRP contracts expiring at the beginning of the 21 st century. The USDA (United States Department of Agriculture) predicted that about 51 percent of CRP land would have returned to crop production if all of its contracts ended in 2001 [37]. The first batch of GGP's contracts concluded at the end of 2012. Currently, the most important problem is to preserve the land conversion achievements of GGP. According to the Table 3, a few orchard lands have already returned to cropland in Yanchuan County, which is a warning sign for the long-term viability of the program. Thus, in the long run, the government should build a continuous compensation mechanism for the households who lost cropland to the GGP, which optimally would align income increases with crop price increases.

As a great deal of cropland was converted to forest, the GGP has led to a remarkable decline of grain production in the GGP regions. For example, the grain output of Yanchuan County was 49.8 thousand tons in 1999, but it was reduced to 26.6 thousand ton in 2011, and its per-capita grain output was reduced to $142.5 \mathrm{~kg}$, which is much less than the national average of $424.0 \mathrm{~kg}$. Therefore, to consolidate the achievements of the GGP, the central government has launched the Basic Survival Cropland Construction Plan (Jiben kouliang tian jianshe) in some GGP regions since 2010. The plan aims to improve the cropland infrastructure and to enhance the productivity of cropland on slopes of less than $15^{\circ}$. By means of the plan, the central government aims to keep the grain yield from declining further in GGP region. Only by enhancing the productivity of existing cropland with slopes of less than 15 degrees and guaranteeing participating households' incomes can the sustainability of the GGP be ensured. 


\section{Conclusions}

Along with China's rapid economic development and population growth, China has been confronted with environmental degradation, as evidenced by severe degradation of grassland, desertification, soil erosion, and massive deforestation. In order to address these increasingly serious environmental problems, a series of state-funded ecological restoration projects have been undertaken in China. Among them, the GGP is the largest land retirement/afforestation program in China in terms of its ambitious goals, massive scales, and huge payments. As a consequence, the effects and influences of the GGP on different areas at different geographical scales have been hotly debate among policymakers and scholars, domestically and internationally. This paper has systematically examined the spatio-temporal patterns of cropland conversion under the GGP, with the focus on the internal structure of converted land and converting land, taking Yanchuan County as a case study. Various research methods including RS, GIS, and personal interviews were employed.

The land use/cover patterns in this case area have changed dramatically from 1999 to 2011 due to the implementation of the GGP policy. Among other things, cropland has decreased remarkably while orchard land and sparse forest land has increased significantly. Approximately $65 \%$ of total orchard land and 54\% of total sparse forest in 2011 were converted from previous cropland. At the same time, the landscape in the case county has become more fragmented and diversified since the GGP policy, and forestland has become a more dominant type of land use. $61.19 \%$ of the total converted cropland was distributed on the slope of more than $15^{\circ}$, and $64.85 \%$ of converted cropland was lower-grade land. The returned cropland is mostly located in more accessible areas so it can be more conveniently managed and supervised. In part affected by farmers' preferences, sloping cropland was more often converted to orchard (economic forest). Some gentle slope (less than $15^{\circ}$ ) or higher-grade cropland was also involved in the GGP, which were not the targeted croplands converted for the GGP. This conversation might lead to reclaim the sloping land and worsen the soil erosion.

Accordingly, there is still a long way to go to maintain and reinforce the achievements of the GGP and further contribute to the GGP's sustainability and rural development. According to the GGP development processes and international experience of the CRP, the Chinese government should further build up continuous compensation mechanisms for the households who lost cropland for the GGP, and improve the productivity of flat cropland as well.

\section{Acknowledgements}

The authors would like to thank Julie Klinger from Department of Geography, University of California, Berkeley for her editorial assistance. Any errors are the sole responsibility of the authors. This work was supported by the National Natural Science Foundation of China (Grant No. 41001109 and 41130748).

\section{Conflicts of Interest}

The authors declare no conflict of interest. 


\section{References}

1. Yeh, E.T. Greening western China: A critical view. Geoforum 2009, 40, 884-894.

2. Liu, J.; Diamond, J. China's environment in a globalizing world. Nature 2005, 435, 1179-1186.

3. WWF (World Wide Fund for Nature). Report Suggests China's Grain-to-Green Plan is Fundamental to Managing Water and Soil Erosion. Available online: http://www.wwfchina.org/ english/loca.php?loca=159 (accessed on 21 March 2003).

4. Zhou, H.; van Rompaey, A.; Wang, J.A. Detecting the impact of the "Grain for Green" program on the mean annual vegetation cover in the Shaanxi province, China using SPOT-VGT NDVI data. Land Use Policy 2009, 26, 954-960.

5. Bullock, A.; King, B. Evaluating China's slope land conversion program as sustainable management in Tianquan and Wuqi Counties. J. Environ. Manag. 2011, 92, 1916-1922.

6. Liu, J.; Li, S.; Ouyang, Z.; Tam, C.; Chen, X. Ecological and socioeconomic effects of China's policies for ecosystem services. Proc. Natl. Acad. Sci. USA 2008, 105, 9477-9482.

7. Cao, S.; Xu, C.; Chen, L.; Wang, X. Attitudes of farmers in China's northern Shaanxi Province towards the land-use changes required under the Grain for Green Project, and implications for the project's success. Land Use Policy 2009, 26, 1182-1194.

8. Xu, Z.; Xu, J.; Deng, X.; Huang, J.; Uchida, E.; Rozelle, S. Grain for green versus grain: Conflict between food security and conservation set-aside in China. World Dev. 2006, 34, 130-148.

9. Uchida, E.; Xu, J.; Rozelle, S. Grain for green: Cost-effectiveness and sustainability of China's conservation set-aside program. Land Econ. 2005, 81, 247-264.

10. Xu, Z.; Bennett, M.T.; Tao, R.; Xu, J. China's sloping land conversion programme four years on: Current situation, pending issues. Int. For. Rev. 2004, 6, 317-326.

11. McVicar, T.R.; Li, L.; van Niel, T.G.; Zhang, L.; Li, R.; Yang, Q.; Zhang, X.; Mu, X.; Wen, Z.; Liu, W. Developing a decision support tool for China's re-vegetation program: Simulating regional impacts of afforestation on average annual streamflow in the Loess Plateau. For. Ecol. Manag. 2007, 251, 65-81.

12. Feng, Q.; Zhao, W.; Qiu, Y.; Zhao, M.; Zhong, L. Spatial heterogeneity of soil moisture and the scale variability of its influencing factors: A case study in the loess plateau of China. Water 2013, 5 , 1226-1242.

13. Egbert, S.L.; Lee, R.Y.; Price, K.P.; Boyce, R.; Nellis, M.D. Mapping conservation reserve program (CRP) grasslands using multi-seasonal thematic mapper imagery. Geocarto Int. 1998, 13, $17-24$.

14. Long, H.; Wu, X.; Wang, W.; Dong, G. Analysis of urban-rural land-use change during 1995-2006 and its policy dimensional driving forces in Chongqing, China. Sensors 2008, 8, 681-699.

15. Kaufmann, R.K.; Seto, K.C. Change detection, accuracy, and bias in a sequential analysis of Landsat imagery in the Pearl River Delta, China: Econometric techniques. Agric. Ecosyst. Environ. 2001, 85, 95-105.

16. Vancutsem, C.; Marinho, E.; Kayitakire, F.; See, L.; Fritz, S. Harmonizing and combining existing land cover/land use datasets for cropland area monitoring at the African continental scale. Remote Sens. 2013, 5, 19-41. 
17. Matejicek, L.; Kopackova, V. Changes in croplands as a result of large scale mining and the associated impact on food security studied using time-series Landsat images. Remote Sens. 2010, 2 , 1463-1480.

18. Martínez, S.; Mollicone, D. From land cover to land use: A methodology to assess land use from remote sensing data. Remote Sens. 2012, 4, 1024-1045.

19. State Forestry Administration. Master Plan for the Sloping Land Conversion Program; Unpublished Report; 2012.

20. Bennett, M.T. China's sloping land conversion program: Institutional innovation or business as usual? Ecol. Econ. 2008, 65, 699-711.

21. Feng, Z.; Yang, Y.; Zhang, Y.; Zhang, P.; Li, Y. Grain-for-green policy and its impacts on grain supply in West China. Land Use Policy 2005, 22, 301-312.

22. Ministry of Land and Resources. China Land \& Resources Almanac 2010; Geological Publishing House: Beijing, China, 2011; pp. 212-214.

23. Zhou, D.; Zhao, S.; Zhu, C. The Grain for Green Project induced land cover change in the Loess Plateau: a case study with Ansai County, Shanxi Province, China. Ecol. Indic. 2012, 23, 88-94.

24. Geospatial Cloud Data. Available online: http://datamirror.csdb.cn (accessed on 12 February 2013).

25. Maxwell, S.; Schmidt, G.; Storey, J. A multi-scale segmentation approach to filling gaps in Landsat ETM+ SLC-off images. Int. J. Remote Sens. 2007, 28, 5339-5356.

26. ASTER Global Digital Elevation Model. Available online: http://www.gdem.aster.ersdac.or.jp/search.jsp (accessed on 9 March 2013).

27. Manandhar, R.; Odeh, I.O.; Ancev, T. Improving the accuracy of land use and land cover classification of Landsat data using post-classification enhancement. Remote Sens. 2009, 1, 330-344.

28. Forestry Bureau of Yanchuan County. The Report of Grain for Green Project of Yanchuan County (1999-2011) (In Chinese); Unpublished Report; 2012.

29. Mcgarigal, K.; Cushman, S.; Neel, M.; Ene, E. FRAGSTATS: Spatial Pattern Analysis Program for Categorical Maps; 2012. Available online: http://www.umass.edu/landeco/research/fragstats/ fragstats.html (accessed on 8 May 2013 ).

30. Committee on Agricultural Regionalization of China. Technical Regulations on Land Use Survey (In Chinese).Chinese Survey\&Mapping Press: Beijing, China, 1984, pp. 5-13.

31. Department of Land and Resources of Shaanxi Province. The 2007 Farmland Gradation of Yanchuan County (In Chinese); Unpublished Report; 2011.

32. Ministry of Land and Resources. Regulation on Cropland Gradation (TD/T 1004-2003); Standards Press of China: Beijing, China, 2003; pp. 10-13.

33. Lele, N.; Nagendra, H.; Southworth, J. Accessibility, demography and protection: Drivers of forest stability and change at multiple scales in the Cauvery Basin, India. Remote Sens. 2010, 2, 306-332.

34. Southworth, J.; Marsik, M.; Qiu, Y.; Perz, S.; Cumming, G.; Stevens, F.; Rocha, K.; Duchelle, A.; Barnes, G. Roads as drivers of change: Trajectories across the tri-national frontier in MAP, the Southwestern Amazon. Remote Sens. 2011, 3, 1047-1066.

35. Krusekopf, C.C. Diversity in land-tenure arrangements under the household responsibility system in China. China Eco. Rev. 2002, 13, 297-312. 
36. Saltiel, J. Controversy over CRP in Montana: Implications for the future. J. Soil Water Conserv. 1994, 49, 284-288.

37. Sullivan, P.; Hellerstein, D.; Hansen, L.; Johansson, R.; Koenig, S.; Lubowski, R.N.; McBride, W.D.; McGranahan, D.A.; Roberts, M.J.; Vogel, S.J. The Conservation Reserve Program: Economic Implications for Rural America; Agricultural Economic Report No. (AER-834); USDA: Washington, DC, USA, 2004.

(C) 2013 by the authors; licensee MDPI, Basel, Switzerland. This article is an open access article distributed under the terms and conditions of the Creative Commons Attribution license (http://creativecommons.org/licenses/by/3.0/). 